\title{
Occurrence of metals in vegetables and fruits from areas near landfill in Southern Italy and implications for human exposure
}

\author{
Valeria Melai* $\mathbb{D}$, Armando Giovannini, Francesco Chiumiento, Mirella Bellocci and Giacomo Migliorati
}

\begin{abstract}
Background: This paper describes the activities and the results obtained from a monitoring of contamination levels of some metals: lead $(\mathrm{Pb})$, cadmium $(\mathrm{Cd})$, mercury $(\mathrm{Hg})$, total arsenic (Astot), vanadium $(\mathrm{V})$, chromium $(\mathrm{Cr})$, antimony $(\mathrm{Sb})$, manganese (Mn) and aluminium (Al) in vegetable food cultivated or sold in local market, near Resit landfill in Giugliano (Campania region, Italy). This area, once well known like Campania felix for abundance and quality of food farming, supplies local, national and community markets. Unfortunately, in the last twenty years, this region has been involved in lots of illegal dumpings of hazardous and urban wastes, that have been periodically set to fire with possible health impact. For this reason it has been renamed as "Terra dei Fuochi" ("Land of Fires").

The aim of this study was the evaluation of the consumers exposure level to metals coming from the intake of likely contaminated vegetables and fruits.

Results: Vegetable and fruit samples was collected in November 2013 on fields and in February 2014 in local markets.

One hundred and thirty-nine samples (peppers, eggplants, lettuces, strawberries and turnip greens) were analysed for metals: fifty-six samples from fields near Resit dump and eighty-three from local markets situated in neighboring provinces and in the southern Lazio.

Metal concentrations in the investigated samples were determined by inductively coupled plasma - mass spectrometry (ICP-MS) or inductively coupled plasma - atomic emission spectrometry (ICP-AES) techniques applying validated and accredited analytical methods.

Conclusions: In all analysed matrices, the level of each investigated metal, highlighted a very low health risk for consumers.

The metal contamination levels measured in this study do not show significant differences compared to relative background values.
\end{abstract}

Keywords: Land of fires, Resit, Heavy metal pollution, Estimated daily intake

\section{Background}

Environmental and agricultural "heavy metal" (International Union of Pure and Applied Chemistry 2002) pollution has always been considered as a result of anthropogenic activities (Luo et al. 2011; Kampa and Castanas 2008; Van Der Voet et al. 2013).

Environmental and food pollution from chemicals which are dangerous to human health is disclosing a

\footnotetext{
* Correspondence: v.melai@izs.it

Istituto Zooprofilattico Sperimentale dell'Abruzzo e del Molise "G. Caporale", Campo Boario, 64100 Teramo, Italy
}

disquieting scenario, due to the following features: 1 ) legitimate or indiscriminate use of pesticide with the aim of preserving crops (Quazi et al. 2013; Wolz et al. 2003); 2) industrial or mining areas as potential sources of environmental pollution (Beccaloni et al. 2013; Ogunkunle and Fatoba 2014); 3) "eco-criminal" actions, e.g. illegal burial of dangerous waste (Di Lorenzo et al. 2015; 14G00013 2016).

Metals can be considered as dangerous chemicals, in particular the so-called "heavy metals", which can cause several serious human diseases. Over the time, a prolonged ingestion of lead, cadmium, mercury and arsenic 
Table 1 Sampling in fields

\begin{tabular}{llll}
\hline Sampling date & Sampling points (field) & Number of farms & Number of samples \\
\hline 6-8 November 2013 & Giugliano in Campania & 2 & 24 (8 peppers, 8 eggplants, 8 lettuces) \\
19 November 2013 & Giugliano in Campania - Villa Literno & 3 & 24 (8 peppers, 8 eggplant, 8 strawberries) \\
7 January 2014 & Giugliano in Campania - Loc. Masseria del Pozzo & 1 & 8 turnip greens \\
\hline
\end{tabular}

originate chronic toxicity (Inaba et al. 2005; Lebel et al. 1998; Vázquez et al. 2015).

The concrete possibility for accidental or criminal contaminations to enhance the amounts of "heavy metals" in food beyond human health tolerance led European Community to establish upper limits for metal amounts in food (OJ L 364 2006). According to European legislation, each European Member State must monitor the presence of lead, cadmium, mercury and arsenic in food.

Other metals such as vanadium, chromium, antimony, aluminium and manganese have been investigated too. Although their maximum limits in food have not been established by European Community yet, such metals could represent a potential risk for human health to be evaluated according to "The precaution principle" (COM/2000/0001 2000).

Thresholds values expressed as e.g. PTWI (Provisional Tolerable Weekly Intake), ADI (Acceptable Daily Intake), NOAEL (Non Observed Adverse Effect Level) concerning the amounts of vanadium, chromium, antimony, aluminium and manganese can be found in the literature, enabling a rigorous assessment of their level of risk for human health (Van Paemel et al. 2010).

In Europe a great deal of polluted sites have been documented, thousands of these in Italy where 57 of them are tagged as Contaminated Sites of National Interest (SIN) subjected to remediation procedures on the bases of the degree of environmental contaminations, health risk and social alarm (DM 471/1991 1999; RSPP 2009-2010 2010). This list includes "Terra dei Fuochi" ("Land of Fires"), an area of Campania region (Southern Italy) involving 55 municipalities characterized by illegal dumping of toxic wastes and uncontrolled combustion of both dangerous and urban solid waste (Additional file 1: Figure S1).

The attention on this SIN "Land of Fires" is linked to the centuries old dedication to this land for the agriculture, renowned for the fertility of volcanic soil and abundance of water.

Advantageous soil and weather conditions of this region have allowed the development of many orchard houses and vegetable gardens in which a lot of different kinds of fruits and vegetables (leaf vegetables, fruit vegetables, root vegetables, flower vegetables) are farmed.

In this area is possible to find not only small farmers able to satisfy the demand of local markets but also farms of larger sizes able to supply local and foreign markets (NTR 24 2016; Agricoltura oggi 2015; Coldiretti 2016; Il sole 24 ore 2014).

The Italians diet, based on "Food Pyramid", firstly takes into account an high consumption of fruit and vegetable which for their abundance of nutrients and protective compounds, are considered essential for a healthy and balanced diet (Piramide Alimentare Italiana 2003; Pellati 2012).
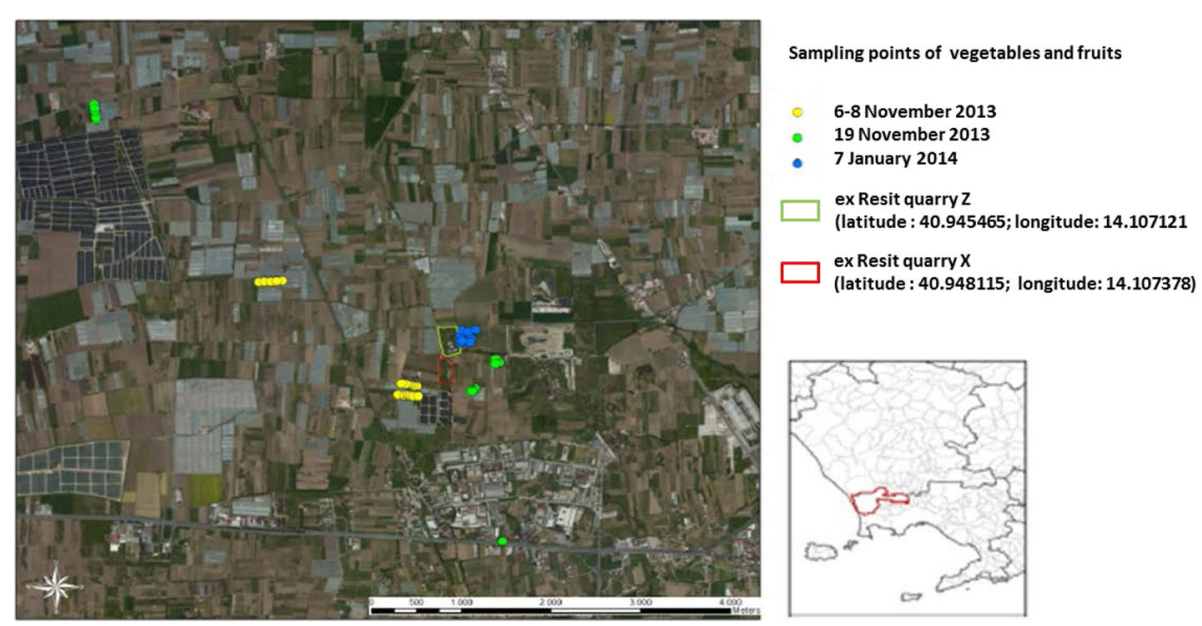

Fig. 1 Map of sampling points of vegetables collected in the fields near Resit landfill 
Table 2 Sampling in the markets

\begin{tabular}{lll}
\hline Sampling date & Sampling points (market) & Number of samples \\
\hline 14 February 2014 & Fondi (LT) & 35 (5 strawberries, 8 lettuces, 8 peppers, 6 eggplants,8 turnip greens) \\
14 February 2014 & Melito di Napoli (NA) & 18 (2 strawberries, 5 lettuces, 4 peppers, 4 eggplants,3 turnip greens) \\
15 February 2014 & Aversa (CE) & 21 (1 strawberries, 2 lettuces, 8 peppers, 5 eggplants,5 turnip greens) \\
15 February 2014 & Parete (CE) & 9 (7 strawberries, 2 lettuces) \\
\hline
\end{tabular}

In 2003, World Health Organization (WHO) and UN Food and Agriculture Organization (FAO) announced a unified approach to promote greater consumption of fruit and vegetable. This recommendation arises from scientific data that identify in low fruit and vegetable intakes a key risk factor for heart diseases, cancer and obesity (FAO/WHO 2003; Ministero delle Politiche Agricole e Forestali/INRAN 2003). For this reason it is necessary to improve the supply of fruits and vegetables to meet global needs and to give a certification of quality of these products.

Currently, the scientific knowledge about the transfer of heavy metals from the soil to the fruits and vegetables and their potential bioaccumulation is still insufficient and conflicting (Luo et al. 2011; Adamo et al. 2014; Rossi and Patanella 2016; Tang et al. 2016; Augustsson et al. 2015; Bashaa et al. 2014). To this aim, institutions and scientific organizations are working to the "Land of Fires" emergency for avoiding unfounded (useless) scaremongering that could confuse consumers and could have serious consequences on the local economy.

Lately, Italian institutions appointed for the monitoring environmental risks have implemented methods targeted to keep metal-based potential injuries under control (SENTIERI 2010).

The present study stands up an emergency raised by Italian mass media, which reported a "heavy metal" contamination of fruits and vegetables grown in the

Table $3 \mathrm{~Pb}, \mathrm{Cd}$, total $\mathrm{As}$ and $\mathrm{Hg}$ in collected samples in fields: minimun and maximum concentration $\left(\mathrm{mg} \mathrm{kg}^{-1}\right)$, Average background value $\left(\mathrm{mg} \mathrm{kg}^{-1}\right), \mathrm{ADI}$ ( $\mathrm{mg} \mathrm{kg}^{-1}$ per body weight per day), EDI (worst-case) ( $\mathrm{mg} \mathrm{kg}^{-1}$ per body weight per day) and the Metal daily quantity ingested respect to ADI (\%); a) Szefer and Nriagu 2007; b) Van Paemel et al. 2010; c) WHO/SDE/WSH/03.04/74 2003 d); INRAN-SCAl 2005-06 2010; e) Leclercq et al. 2009

\begin{tabular}{|c|c|c|c|c|c|c|c|}
\hline Metal & Material & $\begin{array}{l}\text { Minimum } \\
\text { concentration }(*)\end{array}$ & $\begin{array}{l}\text { Maximum } \\
\text { concentration }(*)\end{array}$ & $\begin{array}{l}\text { Average } \\
\text { background value }\end{array}$ & $\left.A D\right|^{b, c}$ & $\begin{array}{l}\text { EDI } \\
\text { (worst-case) }^{\mathrm{d}, \mathrm{e}}\end{array}$ & $\begin{array}{l}\text { Metal daily quantity } \\
\text { ingested respect to ADI (\%) }\end{array}$ \\
\hline \multirow[t]{5}{*}{ LEAD } & Pepper & LOD (0.010) & 0.044 & \multirow[t]{5}{*}{$0.01-0.02$} & \multirow[t]{5}{*}{0.0036} & 0.000020 & 0.6 \\
\hline & Eggplant & LOD (0.010) & 0.035 & & & 0.000040 & 1 \\
\hline & Lettuce & LOD (0.010) & 0.027 & & & 0.000024 & 0.7 \\
\hline & Strawberry & LOD (0.010) & LOQ (0.020) & & & 0.0000066 & 0.2 \\
\hline & Turnip greens & LOQ (0.020) & 0.044 & & & 0.000022 & 0.6 \\
\hline \multirow[t]{5}{*}{ CADMIUM } & Pepper & LOD (0.0010) & 0.020 & \multirow[t]{5}{*}{0.006} & \multirow[t]{5}{*}{0.0001} & 0.0000091 & 9 \\
\hline & Eggplant & LOQ (0.010) & 0.026 & & & 0.000030 & 30 \\
\hline & Lettuce & LOQ (0.010) & 0.019 & & & 0.000017 & 17 \\
\hline & Strawberry & LOD (0.0010) & LOQ (0.010) & & & 0.0000033 & 3 \\
\hline & Turnip greens & LOQ (0.010) & 0.027 & & & 0.000014 & 14 \\
\hline \multirow{5}{*}{$\begin{array}{l}\text { TOTAL } \\
\text { ARSENIC }\end{array}$} & Pepper & LOQ (0.020) & 0.029 & \multirow[t]{5}{*}{0.003} & \multirow[t]{5}{*}{0.005} & 0.000013 & 0.3 \\
\hline & Eggplant & LOQ $(0.020)$ & 0.031 & & & 0.000035 & 0.7 \\
\hline & Lettuce & LOQ (0.020) & 0.020 & & & 0.000018 & 0.4 \\
\hline & Strawberry & LOQ (0.020) & 0.044 & & & 0.000015 & 0.3 \\
\hline & Turnip greens & LOQ (0.020) & 0.076 & & & 0.000039 & 0.8 \\
\hline \multirow[t]{5}{*}{ MERCURY } & Pepper & LOD (0.0050) & LOD (0.0050) & \multirow[t]{5}{*}{0.002} & \multirow[t]{5}{*}{$0.0016\left(^{* *}\right) 0.0003(* * *)$} & 0.0000023 & 0.1 \\
\hline & Eggplant & LOD (0.0050) & LOD (0.0050) & & & 0.0000058 & 0.4 \\
\hline & Lettuce & LOD (0.0050) & LOQ (0.010) & & & 0.0000090 & 0.6 \\
\hline & Strawberry & LOD $(0.0050)$ & LOD (0.0050) & & & 0.0000017 & 0.1 \\
\hline & Turnip greens & LOD (0.0050) & LOQ (0.010) & & & 0.0000051 & 0.3 \\
\hline
\end{tabular}


fields surrounding the Resit dump of Giugliano (Campania region), a village located within the "Land of Fires".

The aim was to determine the concentrations of $\mathrm{Pb}$, $\mathrm{Cd}, \mathrm{Hg}$, total $\mathrm{As}, \mathrm{V}, \mathrm{Cr}, \mathrm{Sb}, \mathrm{Mn}, \mathrm{Al}$ in vegetable products both in fields and marketplaces, to calculate metal daily intake from fruit and vegetable consumers in order to assess the potential health risk.

\section{Methods}

\section{Sampling in fields near Resit landfill}

Sampling was conducted from 2013 November to 2014 January by three consecutive times as reported (Additional file 1: Appendix S1). Fifty-six samples of vegetables from six farms near Resit landfill were collected (Table 1).

Figure 1 shows sampling points and ex Resit quarry.
Every sample, formed from five aliquots of two kilograms, was accompanied by information required for subsequent evaluation and interpretation of results.

The samples were collected in accordance with the Regulation (EC) n. 333/2007 (OJ L 88 2007).

On a total of fifty-six samples of vegetable and fruit products collected, sixteen were pepper samples (two fields), sixteen eggplant samples (two fields), eight lettuce samples (one field), eight strawberry samples (one field) and eight turnip greens samples (one field).

One eggplant collected sample was excluded from the statistical analysis and geographical results, although analysed with compliant result, due to an inaccuracy of its geographic coordinates.

Table $4 \mathrm{~V}, \mathrm{Sb}, \mathrm{Cr}, \mathrm{Al}$ and $\mathrm{Mn}$ in collected samples in fields: minimun and maximum concentration (mg $\mathrm{kg}^{-1}$ ), Average background value ( $\mathrm{mg} \mathrm{kg}^{-1}$ ), ADI ( $\mathrm{mg} \mathrm{kg}^{-1}$ per body weight per day), EDI (worst-case) ( $\mathrm{mg} \mathrm{kg}^{-1}$ per body weight per day) and the Metal daily quantity ingested respect to ADI (\%); b) Van Paemel et al. 2010; c) WHO/SDE/WSH/03.04/74 2003 d); INRAN-SCAI 2005-06 2010; e) Leclercq et al. 2009

\begin{tabular}{|c|c|c|c|c|c|c|c|}
\hline Metal & Material & $\begin{array}{l}\text { Minimum } \\
\text { concentration }(*)\end{array}$ & $\begin{array}{l}\text { Maximum } \\
\text { concentration }(*)\end{array}$ & $\begin{array}{l}\text { Average } \\
\text { background value }\end{array}$ & $A D I^{b, c}$ & 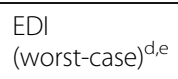 & $\begin{array}{l}\text { Metal daily quantity } \\
\text { ingested respect to ADI (\%) }\end{array}$ \\
\hline \multirow[t]{5}{*}{ VANADIUM } & Pepper & LOD (0.0050) & LOD (0.0050) & n.d. & 0.010 & 0.0000023 & 0.02 \\
\hline & Eggplant & LOD (0.0050) & LOQ (0.010) & & & 0.000012 & 0.1 \\
\hline & Lettuce & LOD (0.0050) & LOQ (0.010) & & & 0.0000090 & 0.1 \\
\hline & Strawberry & LOD (0.0050) & LOD (0.0050) & & & 0.0000017 & 0.02 \\
\hline & Turnip greens & LOQ (0.010) & 0.040 & & & 0.000021 & 0.2 \\
\hline \multirow[t]{5}{*}{ ANTIMONY } & Pepper & LOD (0.0050) & LOD (0.0050) & $0.0002-0.005$ & 0.006 & 0.0000023 & 0.04 \\
\hline & Eggplant & LOD (0.0050) & LOD (0.0050) & & & 0.0000058 & 0.1 \\
\hline & Lettuce & LOD (0.0050) & LOD (0.0050) & & & 0.0000045 & 0.07 \\
\hline & Strawberry & LOD (0.0050) & LOD (0.0050) & & & 0.0000017 & 0.03 \\
\hline & Turnip greens & LOD (0.0050) & 0.071 & & & 0.000036 & 0.6 \\
\hline \multirow[t]{5}{*}{ CHROMIUM } & Pepper & LOD (0.010) & 0.051 & 0.04 & $0.001 \mathrm{Cr}(\mathrm{Vl})$ & 0.000023 & 2 \\
\hline & Eggplant & LOQ (0.020) & 0.055 & & & 0.000064 & 6 \\
\hline & Lettuce & 0.023 & 0.055 & & & 0.000050 & 5 \\
\hline & Strawberry & LOQ (0.020) & 0.032 & & & 0.000011 & 1 \\
\hline & Turnip greens & LOQ (0.020) & 0.043 & & & 0.000022 & 2 \\
\hline \multirow[t]{5}{*}{ ALUMINIUM } & Pepper & 0.26 & 2.0 & 1.8 & 0.150 & 0.00094 & 0.6 \\
\hline & Eggplant & 0.21 & 1.1 & & & 0.0012 & 0.8 \\
\hline & Lettuce & LOQ (0.20) & 0.68 & & & 0.00061 & 0.4 \\
\hline & Strawberry & 1.7 & 5.2 & & & 0.0017 & 1 \\
\hline & Turnip greens & 2.1 & 24 & & & 0.012 & 8 \\
\hline \multirow[t]{5}{*}{ MANGANESE } & Pepper & 0.91 & 1.6 & 1.1 & 0.160 & 0.00073 & 0.5 \\
\hline & Eggplant & 0.91 & 2.4 & & & 0.0027 & 2 \\
\hline & Lettuce & 2.1 & 3.1 & & & 0.0028 & 2 \\
\hline & Strawberry & 1.8 & 2.8 & & & 0.00092 & 0.6 \\
\hline & Turnip greens & 1.8 & 5.7 & & & 0.0029 & 2 \\
\hline
\end{tabular}




\section{Sampling in the local markets}

The sampling was conducted in 2 days in 2014 February. Eighty-three samples of vegetables from four markets [Melito (Napoli), Aversa (Caserta), Parete (Caserta) and Fondi (Latina)] were collected (Table 2).

The chosen markets for sampling were located in two regions, Campania and Lazio, because there was a high probability that the vegetable products originated in fields near Resit landfill.

In the markets the same kind of vegetables and fruits of the fields was collected. The sampling approach for each product (strawberries, peppers, eggplants, lettuces and turnip greens) was:

1) for a number of stands where the vegetable was equal or less than 8 , have been collected samples from all stands; 2) for a number of stands more than 8 , have been chosen 8 stands random for sampling.

Every sample was formed from one aliquot of two kilograms.

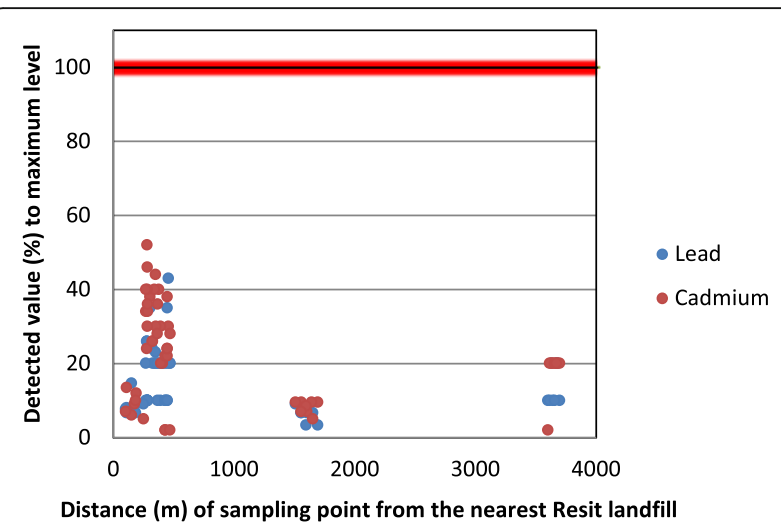

Fig. $2 \mathrm{~Pb}$ and $\mathrm{Cd}$ results. Detected values of $\mathrm{Pb}$ and $\mathrm{Cd}$ contamination, expressed in \% respect to maximum level permitted (Maximum level $=100 \%$ )

Table $5 \mathrm{~Pb}, \mathrm{Cd}$, total As and $\mathrm{Hg}$ in collected samples in markets: minimun and maximum concentration $\left(\mathrm{mg} \mathrm{kg}^{-1}\right)$, Average background value $\left(\mathrm{mg} \mathrm{kg}^{-1}\right), \mathrm{ADI}$ ( $\mathrm{mg} \mathrm{kg}^{-1}$ per body weight per day), EDI (worst-case) ( $\mathrm{mg} \mathrm{kg}^{-1}$ per body weight per day) and the Metal daily quantity ingested respect to ADI (\%); b) Van Paemel et al. 2010; c) WHO/SDE/WSH/03.04/74 2003 d); INRAN-SCAI 2005-06 2010; e) Leclercq et al. 2009

\begin{tabular}{|c|c|c|c|c|c|c|c|}
\hline Metal & Material & $\begin{array}{l}\text { Minimum } \\
\text { concentration }(*)\end{array}$ & $\begin{array}{l}\text { Maximum } \\
\text { concentration }(*)\end{array}$ & $\begin{array}{l}\text { Average } \\
\text { background value }\end{array}$ & $A D l^{b, c}$ & $\begin{array}{l}\text { EDI } \\
\text { (worst-case) }^{\text {d,e }}\end{array}$ & $\begin{array}{l}\text { Metal daily quantity } \\
\text { ingested respect to ADI (\%) }\end{array}$ \\
\hline \multirow[t]{5}{*}{ LEAD } & Pepper & LOD $(0.010)$ & LOQ (0.020) & \multirow[t]{5}{*}{$0.01-0.02$} & \multirow[t]{5}{*}{0.0036} & 0.000009 & 0.3 \\
\hline & Eggplant & LOD (0.010) & LOQ (0.020) & & & 0.000023 & 0.6 \\
\hline & Lettuce & LOD (0.010) & 0.026 & & & 0.000023 & 0.6 \\
\hline & Strawberry & LOD (0.010) & LOQ (0.020) & & & 0.0000066 & 0.2 \\
\hline & Turnip greens & LOQ (0.020) & 0.043 & & & 0.000022 & 0.6 \\
\hline \multirow[t]{5}{*}{ CADMIUM } & Pepper & LOQ (0.010) & 0.016 & \multirow[t]{5}{*}{0.006} & \multirow[t]{5}{*}{0.0001} & 0.0000074 & 7 \\
\hline & Eggplant & LOD (0.0010) & LOQ (0.010) & & & 0.000012 & 12 \\
\hline & Lettuce & LOQ (0.010) & 0.055 & & & 0.000049 & 49 \\
\hline & Strawberry & LOD (0.0010) & LOQ (0.010) & & & 0.0000033 & 3 \\
\hline & Turnip greens & LOQ (0.010) & 0.076 & & & 0.000039 & 39 \\
\hline \multirow[t]{5}{*}{ TOTAL ARSENIC } & Pepper & LOQ (0.020) & 0.097 & \multirow[t]{5}{*}{0.003} & \multirow[t]{5}{*}{0.005} & 0.000045 & 0.9 \\
\hline & Eggplant & LOQ (0.020) & 0.046 & & & 0.000053 & 1 \\
\hline & Lettuce & 0.024 & 0.090 & & & 0.000081 & 2 \\
\hline & Strawberry & LOQ (0.020) & 0.042 & & & 0.000014 & 0.3 \\
\hline & Turnip greens & 0.021 & 0.130 & & & 0.000066 & 1 \\
\hline \multirow[t]{5}{*}{ MERCURY } & Pepper & LOD (0.0050) & LOQ (0.0100) & \multirow[t]{5}{*}{0.002} & \multirow{5}{*}{$\begin{array}{l}0.0016\left(^{(* *)}\right. \\
0.0003\left(^{(* *)}\right.\end{array}$} & 0.0000046 & 0.3 \\
\hline & Eggplant & LOD (0.0050) & LOD (0.0050) & & & 0.0000058 & 0.4 \\
\hline & Lettuce & LOD (0.0050) & LOQ (0.010) & & & 0.0000090 & 0.6 \\
\hline & Strawberry & LOD (0.0050) & LOD (0.0050) & & & 0.0000017 & 0.1 \\
\hline & Turnip greens & LOD (0.0050) & LOQ (0.010) & & & 0.0000051 & 0.3 \\
\hline
\end{tabular}

(*) LOD Limit of detection, LOQ Limit of quantification. (**) $\mathrm{ADI}$ of $\mathrm{Hg} .{ }^{(* * *)} \mathrm{ADI}$ of $\mathrm{CH}_{3} \mathrm{Hg}$ 
The samples were collected in accordance with the Regulation (EC) n. 333/2007 (OJ L 88 2007).

Twenty samples of pepper (three markets), fifteen samples of eggplant (three markets), seventeen samples of lettuce (four markets), fifteen samples of strawberries (four markets) and sixteen samples of turnip greens (three markets) were collected, totally eighty-three samples of vegetable and fruit products.

Every sample was accompanied by information required for subsequent evaluation and interpretation of results.

\section{Determination of metals}

Every sample was analysed to determine levels of lead, cadmium, mercury, total arsenic, vanadium, chromium, antimony, manganese and aluminium.
The sample preparative step was made applying two official methods UNI EN 13804:2013 and UNI EN 13805:2002.

The instrumental analysis of lead, cadmium, mercury, total arsenic, vanadium, chromium and antimony was conducted by inductively coupled plasma mass spectrometry (ICP-MS), for manganese and aluminium determination it was used inductively coupled plasma - atomic emission spectrometry (ICP-AES).

For lead, cadmium, mercury, total arsenic determination it was applied official method UNI EN 15763:2010, accredited and validated according to, respectively, ISO 17025:2005 and Regulation (EC) n. 333/2007 (OJ L 88 2007).

In every session it was analysed a certified reference material as quality control for all investigated metals.

Table $6 \mathrm{~V}$, Sb, $\mathrm{Cr}$, Al and $\mathrm{Mn}$ in collected samples in fields: minimun and maximum concentration ( $\mathrm{mg} \mathrm{kg}^{-1}$ ), Average background value $\left(\mathrm{mg} \mathrm{kg}^{-1}\right), \mathrm{ADI}\left(\mathrm{mg} \mathrm{kg}^{-1}\right.$ per body weight per day), EDI (worst-case) ( $\mathrm{mg} \mathrm{kg}^{-1}$ per body weight per day) and the Metal daily quantity ingested respect to ADI (\%); b) Van Paemel et al. 2010; c) WHO/SDE/WSH/03.04/74 2003 d); INRAN-SCAI 2005-06 2010; e) Leclercq et al. 2009

\begin{tabular}{|c|c|c|c|c|c|c|c|}
\hline Metal & Material & $\begin{array}{l}\text { Minimum } \\
\text { concentration }(*)\end{array}$ & $\begin{array}{l}\text { Maximum } \\
\text { concentration }(*)\end{array}$ & $\begin{array}{l}\text { Average } \\
\text { background value }^{a}\end{array}$ & $A D I^{b, c}$ & $\begin{array}{l}\text { EDI } \\
\text { (worst-case) })^{\text {d,e }}\end{array}$ & $\begin{array}{l}\text { Metal daily quantity } \\
\text { ingested respect to ADI (\%) }\end{array}$ \\
\hline \multirow[t]{5}{*}{ VANADIUM } & Pepper & LOD (0.0050) & 0.0110 & n.d. & 0.010 & 0.0000051 & 0.05 \\
\hline & Eggplant & LOD (0.0050) & LOQ (0.010) & & & 0.000012 & 0.1 \\
\hline & Lettuce & LOD (0.0050) & LOQ (0.010) & & & 0.0000090 & 0.1 \\
\hline & Strawberry & LOD (0.0050) & LOD (0.0050) & & & 0.0000017 & 0.02 \\
\hline & Turnip greens & LOD (0.0050) & 0.042 & & & 0.000021 & 0.2 \\
\hline \multirow[t]{5}{*}{ ANTIMONY } & Pepper & LOD (0.0050) & LOQ (0.0100) & $0.0002-0.005$ & 0.006 & 0.0000046 & 0.08 \\
\hline & Eggplant & LOD (0.0050) & 0.0170 & & & 0.0000196 & 0.3 \\
\hline & Lettuce & LOQ (0.0100) & 0.0120 & & & 0.0000108 & 0.2 \\
\hline & Strawberry & LOD (0.0050) & LOQ (0.0100) & & & 0.0000033 & 0.06 \\
\hline & Turnip greens & LOD (0.0050) & 0.011 & & & 0.000006 & 0.09 \\
\hline \multirow[t]{5}{*}{ CHROMIUM } & Pepper & LOQ (0.020) & 0.072 & 0.04 & $0.001 \mathrm{Cr}(\mathrm{VI})$ & 0.000033 & 3 \\
\hline & Eggplant & LOD (0.010) & 0.039 & & & 0.000045 & 5 \\
\hline & Lettuce & LOQ (0.020) & 0.086 & & & 0.000077 & 8 \\
\hline & Strawberry & LOQ (0.020) & 0.024 & & & 0.000008 & 0.8 \\
\hline & Turnip greens & LOQ (0.020) & 0.058 & & & 0.000030 & 3 \\
\hline \multirow[t]{5}{*}{ ALUMINIUM } & Pepper & LOD (0.20) & 20 & 1.8 & 0.150 & 0.00920 & 6 \\
\hline & Eggplant & LOD (0.20) & 0.34 & & & 0.0004 & 0.3 \\
\hline & Lettuce & 0.26 & 5.2 & & & 0.00468 & 3 \\
\hline & Strawberry & 0.43 & 3.1 & & & 0.0010 & 0.7 \\
\hline & Turnip greens & 2.2 & 24 & & & 0.012 & 8 \\
\hline \multirow[t]{5}{*}{ MANGANESE } & Pepper & 0.53 & 1.3 & 1.1 & 0.160 & 0.00060 & 0.4 \\
\hline & Eggplant & 1.0 & 3.2 & & & 0.0037 & 2 \\
\hline & Lettuce & 0.26 & 3.9 & & & 0.0035 & 2 \\
\hline & Strawberry & 0.70 & 9.9 & & & 0.00327 & 2 \\
\hline & Turnip greens & 1.3 & 4.8 & & & 0.0024 & 2 \\
\hline
\end{tabular}




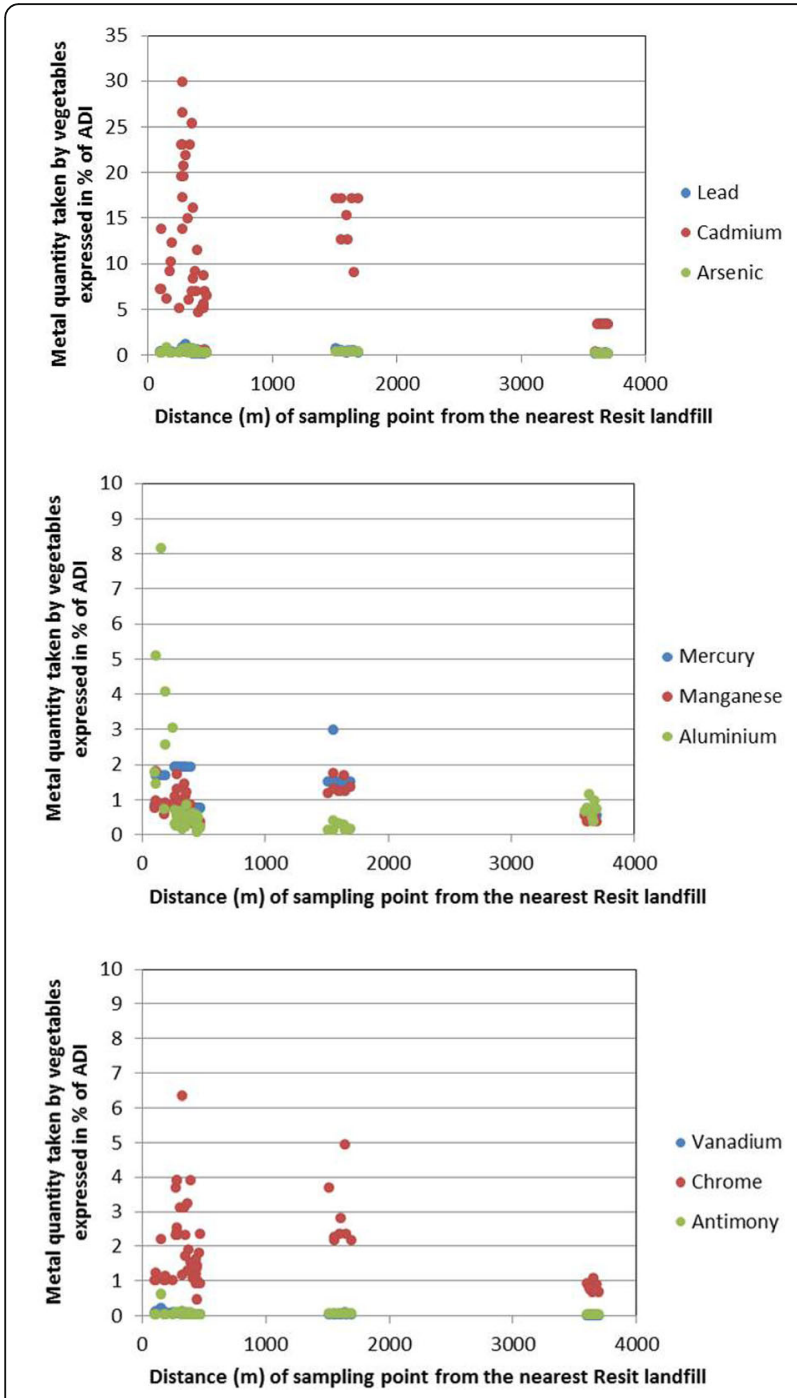

Fig. 3 Sampling in fields: estimated exposure to metals by vegetables consumption expressed in \% in function of Acceptable Daaily Intake (ADI = 100\%)

\section{Reagents and standards}

Single element $1000 \mathrm{mg} \mathrm{L}^{-1}$ stock standard solutions of $\mathrm{Pb}, \mathrm{Cd}, \mathrm{Hg}$, total As, V, Cr, Sb, Mn, Al, Ga (Gallium), In (Indium), Re (Rhenium) and Y (Yttrium) of trace analysis grade were purchased from Sigma-Aldrich. Certified reference material BCR 1573a tomato leaves was supplied by Sigma-Aldrich (St. Louis, MO, USA) and reference material Fapas 07116 vegetable purèe was purchased from FAPAS (Fera Science Ltd., Sand Hutton YORK, UK).

All solutions were prepared with high-purity water of 18.2 $\mathrm{M} \Omega \mathrm{cm}^{-1}$ resistivity obtained from a PURELAB Option-Q Elga Veolia (Pordenone, Italy). Reagents used for the sample digestion were nitric acid $\left(\mathrm{HNO}_{3} \geq 69 \%\right.$, TraceSELECT, Sigma-Aldrich, St. Louis, MO, USA), and oxygen peroxide $\left(\mathrm{H}_{2} \mathrm{O}_{2}\right.$ Suprapur 30\%, Merck,
Darmstadt, Germany). Argon gas 5.5 of $99.9995 \%$ purity was supplied by Sapio (Monza, Italy).

\section{Sample preparation}

Before the analysis, all apparatus and glassware, intended to come into direct contact with the sample, were treated with $1 \div 2 \% \mathrm{HNO}_{3}$ and then rinsed with highpurity water.

About $1 \mathrm{~g}$ of homogenized sample was weighed into PTFE vessels and dissolved in $5 \mathrm{~mL} 69 \% \mathrm{HNO}_{3}$ and $1 \mathrm{~mL} 30 \% \mathrm{H}_{2} \mathrm{O}_{2}$. Mineralization was performed in a Multiwave 3000 microwave digestion system (Anton Paar, Graz, Austria) according to the program shown in Additional file 1: Table S1.

After cooling, the resulting clear solutions were quantitatively transferred into decontaminated volumetric flasks and diluted exactly to a volume of $15 \mathrm{~mL}$ with high-purity water.

Spiked samples, blank solutions and reference materials were prepared with the same procedure.

The analytical quality control was verified using spiked samples, reference material Fapas 07116 for lead and certified reference material BCR 1573a for all the other investigated metals.

\section{Instrumental analysis - ICP-MS}

Analysis of $\mathrm{Pb}, \mathrm{Cd}, \mathrm{Hg}$, total $\mathrm{As}, \mathrm{V}, \mathrm{Cr}$ and $\mathrm{Sb}$ was carried out with an inductively coupled plasma mass spectrometer Elan DRC II (PerkinElmer, Waltham, MA, USA). The measurement was performed using standard addition method and $\mathrm{Ga}$, In, Re as internal standards.

Sample introduction was carried out using a peristaltic pump connected to a Meinhard nebulizer with a cyclonic spray chamber. The radio frequency (RF) power was set in the range $1150 \div 1300 \mathrm{~W}$, the plasma gas flow was $15 \mathrm{~L} \mathrm{Ar} \min ^{-1}$, whereas the nebulizer gas flow was daily optimized in the range $0.91 \div 0.93 \mathrm{~L} \mathrm{Ar} \mathrm{min}^{-1}$.

The standard addition calibration method was used to quantify the element of interest using the isotopes reported in Additional file 1: Table S2.

Six standard additions ranging from 1 to $50 \mu \mathrm{g} \mathrm{L} \mathrm{L}^{-1}$ were made and $\mathrm{Re}, \mathrm{Ga}$ and In were used as internal standards at the relative concentrations of 10,20 and $4 \mu \mathrm{g} \mathrm{L}^{-1}$ in all solutions (standards, blanks and samples), in order to compensate any random signal fluctuations.

Diluted solutions were prepared with the same nitric acid concentration of calibration standards $(1 \div 2 \% \mathrm{v} / \mathrm{v})$.

To avoid $\mathrm{Hg}$ memory effects in the sample introduction system (tube of peristaltic pump, nebulizer, spray chamber), after each solution injected, a rinse with a solution $2 \mathrm{mg} \mathrm{L}^{-1} \mathrm{AuCl}_{3}$ was performed for $45 \mathrm{~s}$ at least.

Instrumental general operating parameters are shown in Additional file 1: Table S3. 


\section{Instrumental analysis - ICP-AES}

Analysis of $\mathrm{Mn}$ and $\mathrm{Al}$ was carried out with an inductively coupled plasma atomic emission spectrometer Optima 3000 (PerkinElmer, Waltham, MA, USA). The measurements were performed at 293.305 and $396.153 \mathrm{~nm}$ respectively by an external calibration with $\mathrm{Y}$ as internal standard (371.029 $\mathrm{nm})$.

Sample introduction was carried out using a peristaltic pump connected to a Mira Mist nebulizer with a cyclonic spray chamber. The RF power was set in the range $1300 \div 1350 \mathrm{~W}$, the plasma gas flow was $15 \mathrm{~L} \mathrm{Ar} \mathrm{min}^{-1}$, the nebulizer gas flow was optimized in the range $0.6 \div$ $0.7 \mathrm{~L} \mathrm{Ar} \min ^{-1}$.

Instrumental general operating parameters are shown in Additional file 1: Table S4.

\section{Vegetable products consumption data analysis}

Vegetable consumption data was extracted from an Italian survey of 2 years $(2005-2006)$ by National Research Institute of Food and Nutrition (INRAN) regarding the food consumption in Italy (INRAN-SCAI 2005-06, 2010).
It was considered the bracket of population with age ranging from 10 to 18 years. The average estimated weight of this population was $52.6 \mathrm{~kg}$ (Leclercq et al. 2009).

Health risk assessment of $\mathrm{Pb}, \mathrm{Cd}, \mathrm{Hg}, \mathrm{As}, \mathrm{V}, \mathrm{Cr}, \mathrm{Sb}, \mathrm{Mn}, \mathrm{Al}$ In order to assess a potential health risk to the local consumers by ingestion of metal contaminants derived from investigated vegetable products it was applied the following formula that shows an estimated daily intake (EDI):

$$
\mathrm{EDI}(\mathrm{mg} \text { Metal } / \mathrm{kg} \text { per body weight per day })=\frac{C_{\text {Metal }} \times Q}{B W_{\text {average }}}
$$

Where $C_{\text {Metal }}$ is the measured concentration of metal in fresh vegetable $\left(\mathrm{mg} \mathrm{kg}^{-1}\right), Q$ is the quantity of daily vegetable ingested $(\mathrm{kg})$ and $B W_{\text {average }}$ is the estimated average body weight $(52.6 \mathrm{~kg})$.

\section{Results and discussion}

In Additional file 1: Tables S5, S6 and S7 are shown the metal concentrations expressed in $\mathrm{mg} \mathrm{kg}^{-1}$ wet weight on samples collected from fields, whereas in Additional

Table $7 \mathrm{~Pb}, \mathrm{Cd}$, total $\mathrm{As}$ and $\mathrm{Hg}$ in collected samples in fields: medium concentration $\left(\mathrm{mg} \mathrm{kg}^{-1}\right)$, ADI (mg kg ${ }^{-1}$ per body weight per day), EDI (medium concentration) ( $\mathrm{mg} \mathrm{kg}^{-1}$ per body weight per day), Metal daily quantity ingested respect to ADI (\%) and ratio of EDI (worst case) to EDI (medium concentration); a) Szefer and Nriagu 2007; b) Van Paemel et al. 2010; c) WHO/SDE/WSH/03.04/74 2003 d); INRAN-SCAI 2005-06 2010; e) Leclercq et al. 2009

\begin{tabular}{|c|c|c|c|c|c|c|}
\hline Metal & Material & $\begin{array}{l}\text { Medium } \\
\text { concentration }(*)\end{array}$ & $\left.A D\right|^{b, c}$ & $\begin{array}{l}\text { EDI(medium } \\
\text { concentration) })^{\text {d,e }}\end{array}$ & $\begin{array}{l}\text { Metal daily quantity } \\
\text { ingested respect to ADI (\%) }\end{array}$ & $\begin{array}{l}\text { EDI (worst case) /EDI } \\
\text { (medium concentration) }\end{array}$ \\
\hline \multirow[t]{5}{*}{ LEAD } & Pepper & 0.019 & \multirow[t]{5}{*}{0.0036} & 0.0000013 & 0.036 & 15 \\
\hline & Eggplant & 0.018 & & 0.0000027 & 0.074 & 15 \\
\hline & Lettuce & 0.018 & & 0.0000050 & 0.14 & 5 \\
\hline & Strawberry & 0.014 & & 0.00000068 & 0.019 & 10 \\
\hline & Turnip greens & 0.026 & & 0.0000016 & 0.043 & 14 \\
\hline \multirow[t]{5}{*}{ CADMIUM } & Pepper & 0.012 & \multirow[t]{5}{*}{0.0001} & 0.00000082 & 0.82 & 11 \\
\hline & Eggplant & 0.017 & & 0.0000026 & 2.6 & 11 \\
\hline & Lettuce & 0.016 & & 0.0000044 & 4.4 & 4 \\
\hline & Strawberry & 0.0089 & & 0.00000044 & 0.44 & 8 \\
\hline & Turnip greens & 0.017 & & 0.0000011 & 1.1 & 13 \\
\hline \multirow[t]{5}{*}{ Total ARSENIC } & Pepper & 0.022 & \multirow[t]{5}{*}{0.005} & 0.0000016 & 0.031 & 8 \\
\hline & Eggplant & 0.024 & & 0.0000036 & 0.073 & 10 \\
\hline & Lettuce & 0.020 & & 0.0000054 & 0.11 & 3 \\
\hline & Strawberry & 0.025 & & 0.0000012 & 0.025 & 12 \\
\hline & Turnip greens & 0.028 & & 0.0000017 & 0.035 & 23 \\
\hline \multirow[t]{5}{*}{ MERCURY } & Pepper & 0.0050 & \multirow{5}{*}{$\begin{array}{l}0.0016\left(^{* *}\right) \\
0.0003(* * *)\end{array}$} & 0.00000035 & 0.022 & 7 \\
\hline & Eggplant & 0.0050 & & 0.00000075 & 0.047 & 8 \\
\hline & Lettuce & 0.0056 & & 0.0000015 & 0.095 & 6 \\
\hline & Strawberry & 0.0050 & & 0.00000025 & 0.015 & 7 \\
\hline & Turnip greens & 0.0069 & & 0.00000042 & 0.026 & 12 \\
\hline
\end{tabular}

$\left(^{*}\right)$ It was applied the upper bound approach (EFSA Scientific report(2010)) to calculate the medium concentration. The data not-detected was equal to value of LOD and the data not-quantified was equal to LOQ. $\left.{ }^{* *}\right) \mathrm{ADI}$ of $\left.\mathrm{Hg} .{ }^{(* *}\right) \mathrm{ADI}$ of $\mathrm{CH}_{3} \mathrm{Hg}$ 
Table $8 \mathrm{~V}, \mathrm{Sb}, \mathrm{Cr}, \mathrm{Al}$ and $\mathrm{Mn}$ in collected samples in fields: medium concentration ( $\mathrm{mg} \mathrm{kg}^{-1}$ ), ADI (mg kg ${ }^{-1}$ per body weight per day), EDI (medium concentration) ( $\mathrm{mg} \mathrm{kg}^{-1}$ per body weight per day), Metal daily quantity ingested respect to ADI (\%) and ratio of EDI (worst case) to EDI (medium concentration); a) Szefer and Nriagu 2007; b) Van Paemel et al. 2010; c) WHO/SDE/WSH/03.04/74 2003 d); INRAN-SCAI 2005-06 2010; e) Leclercq et al. 2009

\begin{tabular}{|c|c|c|c|c|c|c|}
\hline Metal & Material & $\begin{array}{l}\text { Medium } \\
\text { concentration }(*)\end{array}$ & $A D I^{b, c}$ & $\begin{array}{l}\text { EDI(medium } \\
\text { concentration) d,e }\end{array}$ & $\begin{array}{l}\text { Metal daily quantity } \\
\text { ingested respect to ADI (\%) }\end{array}$ & $\begin{array}{l}\text { EDI (worst case) /EDI } \\
\text { (medium concentration) }\end{array}$ \\
\hline \multirow[t]{5}{*}{ VANADIUM } & Pepper & 0.0050 & 0.010 & 0.00000035 & 0.0035 & 7 \\
\hline & Eggplant & 0.0053 & & 0.00000080 & 0.0080 & 15 \\
\hline & Lettuce & 0.0056 & & 0.0000015 & 0.015 & 6 \\
\hline & Strawberry & 0.0050 & & 0.00000025 & 0.0025 & 7 \\
\hline & Turnip greens & 0.019 & & 0.0000012 & 0.012 & 18 \\
\hline \multirow[t]{5}{*}{ ANTIMONY } & Pepper & 0.0050 & 0.006 & 0.00000035 & 0.0059 & 7 \\
\hline & Eggplant & 0.0050 & & 0.00000075 & 0.013 & 8 \\
\hline & Lettuce & 0.0050 & & 0.0000013 & 0.022 & 3 \\
\hline & Strawberry & 0.0050 & & 0.00000025 & 0.0041 & 7 \\
\hline & Turnip greens & 0.013 & & 0.00000081 & 0.013 & 45 \\
\hline \multirow[t]{5}{*}{ CHROMIUM } & Pepper & 0.029 & $0.001 \mathrm{Cr}(\mathrm{VI})$ & 0.0000021 & 0.21 & 11 \\
\hline & Eggplant & 0.027 & & 0.0000041 & 0.41 & 16 \\
\hline & Lettuce & 0.031 & & 0.0000085 & 0.85 & 6 \\
\hline & Strawberry & 0.024 & & 0.0000012 & 0.12 & 9 \\
\hline & Turnip greens & 0.024 & & 0.0000014 & 0.14 & 15 \\
\hline \multirow[t]{5}{*}{ ALUMINIUM } & Pepper & 1.2 & 0.150 & 0.000084 & 0.056 & 11 \\
\hline & Eggplant & 0.57 & & 0.000086 & 0.058 & 14 \\
\hline & Lettuce & 0.38 & & 0.00010 & 0.068 & 6 \\
\hline & Strawberry & 3.3 & & 0.00016 & 0.11 & 10 \\
\hline & Turnip greens & 9.8 & & 0.00059 & 0.40 & 20 \\
\hline \multirow[t]{5}{*}{ MANGANESE } & Pepper & 1.2 & 0.160 & 0.000087 & 0.055 & 8 \\
\hline & Eggplant & 1.4 & & 0.00022 & 0.13 & 13 \\
\hline & Lettuce & 2.4 & & 0.00066 & 0.41 & 4 \\
\hline & Strawberry & 2.2 & & 0.00011 & 0.069 & 8 \\
\hline & Turnip greens & 3.0 & & 0.00018 & 0.11 & 16 \\
\hline
\end{tabular}

(*) It was applied the upper bound approach (EFSA Scientific report(2010)) to calculate the medium concentration. The data not-detected was equal to value of LOD and the data not-quantified was equal to LOQ

file 1: Tables S8, S9, S10, S11 and S12 on samples collected from local markets.

Regulation (EC) n. 1881/2006 (OJ L 364 2006) sets maximum levels for lead and cadmium in vegetable products for human foodstuffs (Additional file 1: Table S13); according to this regulation the maximum concentration of lead in peppers, eggplants and strawberries was $0.10 \mathrm{mg} \mathrm{kg}{ }^{-1}$ wet weight, instead in lettuces and turnip greens was $0.30 \mathrm{mg} \mathrm{kg}^{-1}$ wet weight. The maximum concentration of cadmium in peppers, eggplants and strawberries was $0.050 \mathrm{mg} \mathrm{kg} \mathrm{g}^{-1}$ wet weight, in lettuces and turnip greens was $0.20 \mathrm{mg} \mathrm{kg}{ }^{-1}$ wet weight.

All examinated samples were compliant for lead and cadmium.
The lead and cadmium results of the samples collected on the fields related to the distance of sampling point from the nearest Resit dump are reported in Fig. 2.

The European Commission has not established maximum acceptable concentration for arsenic, mercury, vanadium, antimony, chromium, manganese and aluminium in vegetable food, therefore it is not possible to establish the compliance of samples.

The metal concentrations measured in all analysed samples, were evaluated with regard to public health based on literature information (e.g. ADI).

Tables 3, 4, 5, 6 show ADI for each metal related to vegetables as components of national average diet and background contamination avalaible values (WHO/SDE/ WSH/03.04/74. 2003). 
Table $9 \mathrm{~Pb}, \mathrm{Cd}$, total $\mathrm{As}$ and $\mathrm{Hg}$ in collected samples in markets: medium concentration $\left(\mathrm{mg} \mathrm{kg}^{-1}\right)$, ADI (mg kg ${ }^{-1}$ per body weight per day), EDI (medium concentration) ( $\mathrm{mg} \mathrm{kg}^{-1}$ per body weight per day), Metal daily quantity ingested respect to ADI (\%) and ratio of EDI (worst case) to EDI (medium concentration); a) Szefer and Nriagu 2007; b) Van Paemel et al. 2010; c) WHO/SDE/WSH/03.04/74 2003 d); INRAN-SCAI 2005-06 2010; e) Leclercq et al. 2009

\begin{tabular}{|c|c|c|c|c|c|c|}
\hline Metal & Material & $\begin{array}{l}\text { Medium } \\
\text { concentration(*) }\end{array}$ & $A D D^{b, c}$ & $\begin{array}{l}\text { EDI(medium } \\
\text { concentration) }^{\mathrm{d}, \mathrm{e}}\end{array}$ & $\begin{array}{l}\text { Metal daily quantity } \\
\text { ingested respect to ADI (\%) }\end{array}$ & $\begin{array}{l}\text { EDI (worst case) /EDI } \\
\text { (medium concentration) }\end{array}$ \\
\hline \multirow[t]{5}{*}{ LEAD } & Pepper & 0.012 & \multirow[t]{5}{*}{0.0036} & 0.00000084 & 0.023 & 11 \\
\hline & Eggplant & 0.011 & & 0.0000016 & 0.045 & 14 \\
\hline & Lettuce & 0.014 & & 0.0000037 & 0.10 & 6 \\
\hline & Strawberry & 0.011 & & 0.00000053 & 0.015 & 13 \\
\hline & Turnip greens & 0.025 & & 0.0000015 & 0.043 & 14 \\
\hline \multirow[t]{5}{*}{ CADMIUM } & Pepper & 0.010 & \multirow[t]{5}{*}{0.0001} & 0.00000073 & 0.73 & 10 \\
\hline & Eggplant & 0.006 & & 0.00000087 & 0.9 & 14 \\
\hline & Lettuce & 0.019 & & 0.0000051 & 5.1 & 10 \\
\hline & Strawberry & 0.0064 & & 0.00000032 & 0.32 & 10 \\
\hline & Turnip greens & 0.018 & & 0.0000011 & 1.1 & 36 \\
\hline \multirow[t]{5}{*}{ Total ARSENIC } & Pepper & 0.037 & \multirow[t]{5}{*}{0.005} & 0.0000026 & 0.052 & 17 \\
\hline & Eggplant & 0.031 & & 0.0000046 & 0.092 & 12 \\
\hline & Lettuce & 0.056 & & 0.0000151 & 0.30 & 5 \\
\hline & Strawberry & 0.023 & & 0.0000011 & 0.022 & 12 \\
\hline & Turnip greens & 0.060 & & 0.0000036 & 0.073 & 18 \\
\hline \multirow[t]{5}{*}{ MERCURY } & Pepper & 0.0053 & \multirow{5}{*}{$\begin{array}{l}0.0016\left(^{(* *}\right) \\
0.0003\left(^{* * *}\right)\end{array}$} & 0.00000037 & 0.023 & 12 \\
\hline & Eggplant & 0.0050 & & 0.00000075 & 0.047 & 8 \\
\hline & Lettuce & 0.0053 & & 0.0000014 & 0.089 & 6 \\
\hline & Strawberry & 0.0050 & & 0.00000025 & 0.015 & 7 \\
\hline & Turnip greens & 0.0059 & & 0.00000036 & 0.023 & 14 \\
\hline
\end{tabular}

(*) It was applied the upper bound approach (EFSA Scientific report(2010)) to calculate the medium concentration. The data not-detected was equal to value of LOD and the data not-quantified was equal to LOQ. (**) $\mathrm{ADI}$ of $\mathrm{Hg}$. (***) $\mathrm{ADI}$ of $\mathrm{CH}_{3} \mathrm{Hg}$

In order to estimate the quantity of contaminant daily ingested, it was considered the worst-case: maximum concentration measured of every metal and, with precautionary approach, the more exposed consumers, those from 10 to 18 years. The estimated average body weight for this category is $52.6 \mathrm{~kg}$.

In addition, the 95th percentile of daily consumption quantity of each kind of vegetables is $24.2 \mathrm{~g}$ peppers, $60.5 \mathrm{~g}$ eggplants, $47.3 \mathrm{~g}$ lettuces, $17.4 \mathrm{~g}$ strawberries and $26.8 \mathrm{~g}$ turnip greens (INRAN-SCAI 2005-06 2010).

Then it was estimated the daily comsumption level of contaminant on each vegetables in $\mathrm{mg}$ per $\mathrm{kg}$ body weight.

Tables 3, 4, 5, 6 show, for all analysed matrices, that the daily acceptable level of investigated metals is not ever exceeded, also considering the maximum value measured.

The assumption of every contaminant investigated by ingestion of local vegetable products does not exceed, for each kind of analysed food, the 9\% of relative $\mathrm{ADI}$, with the exception of cadmium, whose concentration, however, is not greater than $50 \%$ of its ADI.

For chromium it was considered, with precautionary approach, the ADI of chromium (VI) notoriously toxic because its concentration is a part of total measure (the assumption of chromium by ingestion of investigated vegetables is lower $9 \%$ of its ADI).

The estimated exposition values of the samples collected in the fields related to the distance of sampling point from the nearest Resit dump, are reported in Fig. 3.

Since chronic food poisoning by metal is frequent, in order to estimate the daily contaminant quantity ingested, it was considered the medium concentration measured of every metal and the most exposed consumers (teenagers: 10 to 18 years). The estimated average body weight for this category is $52.6 \mathrm{~kg}$.

In addition, the mean of daily consumption of each kind of vegetables is $3.7 \mathrm{~g}$ peppers, $7.9 \mathrm{~g}$ eggplants, $14.2 \mathrm{~g}$ lettuces, $2.6 \mathrm{~g}$ strawberries and $3.2 \mathrm{~g}$ turnip greens (INRAN-SCAI 2005-06 2010). 
Table $10 \mathrm{~V}, \mathrm{Sb}, \mathrm{Cr}, \mathrm{Al}$ and $\mathrm{Mn}$ in collected samples in markets: medium concentration $\left(\mathrm{mg} \mathrm{kg}^{-1}\right)$, ADI (mg kg ${ }^{-1}$ per body weight per day), EDI (medium concentration) ( $\mathrm{mg} \mathrm{kg}^{-1}$ per body weight per day), Metal daily quantity ingested respect to ADI (\%) and ratio of EDI (worst case) to EDI (medium concentration); a) Szefer and Nriagu 2007; b) Van Paemel et al. 2010; c) WHO/SDE/WSH/03.04/74 2003 d); INRAN-SCAI 2005-06 2010; e) Leclercq et al. 2009

\begin{tabular}{|c|c|c|c|c|c|c|}
\hline Metal & Material & $\begin{array}{l}\text { Medium } \\
\text { concentration }\left({ }^{*}\right)\end{array}$ & $A D I^{b, c}$ & $\begin{array}{l}\text { EDI(medium } \\
\text { concentration) }^{\text {d,e }}\end{array}$ & $\begin{array}{l}\text { Metal daily quantity } \\
\text { ingested respect to ADI (\%) }\end{array}$ & $\begin{array}{l}\text { EDI (worst case) /EDI } \\
\text { (medium concentration) }\end{array}$ \\
\hline \multirow[t]{5}{*}{ VANADIUM } & Pepper & 0.0053 & 0.010 & 0.00000037 & 0.0037 & 14 \\
\hline & Eggplant & 0.0057 & & 0.00000085 & 0.0085 & 14 \\
\hline & Lettuce & 0.0053 & & 0.0000014 & 0.014 & 6 \\
\hline & Strawberry & 0.0050 & & 0.00000025 & 0.0025 & 7 \\
\hline & Turnip greens & 0.023 & & 0.0000014 & 0.014 & 15 \\
\hline \multirow[t]{5}{*}{ ANTIMONY } & Pepper & 0.0053 & 0.006 & 0.00000037 & 0.0062 & 12 \\
\hline & Eggplant & 0.0068 & & 0.0000010 & 0.017 & 19 \\
\hline & Lettuce & 0.0102 & & 0.0000027 & 0.046 & 4 \\
\hline & Strawberry & 0.0063 & & 0.00000031 & 0.0052 & 11 \\
\hline & Turnip greens & 0.009 & & 0.00000057 & 0.010 & 10 \\
\hline \multirow[t]{5}{*}{ CHROMIUM } & Pepper & 0.024 & $0.001 \mathrm{Cr}(\mathrm{Vl})$ & 0.0000017 & 0.17 & 19 \\
\hline & Eggplant & 0.021 & & 0.0000031 & 0.31 & 14 \\
\hline & Lettuce & 0.027 & & 0.0000073 & 0.73 & 11 \\
\hline & Strawberry & 0.020 & & 0.0000010 & 0.10 & 8 \\
\hline & Turnip greens & 0.033 & & 0.0000020 & 0.20 & 15 \\
\hline \multirow[t]{5}{*}{ ALUMINIUM } & Pepper & 1.7 & 0.150 & 0.00012 & 0.080 & 77 \\
\hline & Eggplant & 0.22 & & 0.000033 & 0.022 & 12 \\
\hline & Lettuce & 1.3 & & 0.00036 & 0.24 & 13 \\
\hline & Strawberry & 1.2 & & 0.000057 & 0.038 & 18 \\
\hline & Turnip greens & 9.7 & & 0.00059 & 0.39 & 20 \\
\hline \multirow[t]{5}{*}{ MANGANESE } & Pepper & 0.9 & 0.160 & 0.000064 & 0.040 & 9 \\
\hline & Eggplant & 1.6 & & 0.00024 & 0.15 & 15 \\
\hline & Lettuce & 1.1 & & 0.00030 & 0.19 & 12 \\
\hline & Strawberry & 2.9 & & 0.00014 & 0.089 & 23 \\
\hline & Turnip greens & 3.1 & & 0.00019 & 0.12 & 13 \\
\hline
\end{tabular}

(*) It was applied the upper bound approach (EFSA Scientific report (2010)) to calculate the medium concentration. The data not-detected was equal to value of LOD and the data not-quantified was equal to LOQ

Then it was estimated the daily comsumption level of contaminant on each vegetables in $\mathrm{mg}$ per $\mathrm{kg}$ body weight.

The Tables 7, 8, 9, 10 show, for all analysed matrices, the assumption of every contaminant investigated in "normal conditions" (average metal level concentration referred to the mean of food consumption).

Then, it was compared the contamination levels measured in the analysed samples to the relative background contamination value in Europe reported in literature (WHO/SDE/WSH/03.04/74 2003; Szefer and Nriagu 2007). The reported values are guidance only because depending on several factors such as geographical area, the type of soil, the type of plant, the bioavailability of the individual elements, etc. The comparison between the levels measured in this monitoring and the bottom does not show substantial differences.

Tables 3, 4, 5, 6 show ADI related to vegetables as components of national average diet and background contamination avalaible values.

\section{Conclusions}

The aim of this study was the evaluation of consumers exposure level to some metals (lead, cadmium, total arsenic, mercury, aluminium, manganese, vanadium, antimony and chromium), throught the intake of vegetables and fruits, potential subjects to polluting effects caused by proximity Resit landfill.

This monitoring obtained the following considerations: 
1. all samples tested for lead and cadmium, collected in the fields near to Resit landfill and in local markets, were compliants with European Regulation (OJ L 364 2006);

2. in all analysed matrices, the level of each investigated metal does not exceed the acceptable daily intake, considering the worst-case (at the concentration value as the maximum level determined and at 95th of daily vegetable consumption). The intake of each analysed contaminant through the consumption of local vegetables and fruits, does not exceed, for all tested matrices, the $9 \%$ of relative ADI. Although cadmium is the only one exception, it does not exceed $50 \%$ of its ADI;

3. in all analysed matrices, the level of each investigated metal, considering "normal conditions" (at the average concentration level and at the mean quantity of vegetable consumption) is much lower than worst-case (from 3 to 45 times in field products and from 4 to 77 times in market vegetables);

4. since it could not be obtained any control samples from similar regions at lower risks of environmental pollution due to several factors (e.g. type of soil), the metal contamination levels measured in this study were compared with relative background values. This comparison does not highlight significant differences.

\section{Additional file}

Additional file 1: Figure S1. Map of area renamed as "Terra dei Fuochi" ("Land of Fires"). Table S1. Parameters for microwave oven program. Table S2. Quantification isotopes, internal standards and acquisition mode. Table S3. Instrumental parameters ICP-MS. Table S4. Instrumental parameters ICP-AES. Table S5. Metal results ( $\mathrm{mg} / \mathrm{kg}$ wet weight) of collected samples in field (2013, 6th- 8th November). Table S6. Metal results ( $\mathrm{mg} / \mathrm{kg}$ wet weight) of collected samples in field $(2013,19$ th November). Table S7. Metal results ( $\mathrm{mg} / \mathrm{kg}$ wet weight) of collected samples in field (7th January 2014). Table S8. Metal results ( $\mathrm{mg} / \mathrm{kg}$ wet weight) of collected strawberries in the markets $(2014,14$ th - 15th February). Table S9. Metal results ( $\mathrm{mg} / \mathrm{kg}$ wet weight) of collected lettuces in the markets (2014, 14th - 15th February). Table S10. Metal results ( $\mathrm{mg} / \mathrm{kg}$ wet weight) of collected eggplants in the markets (2014, 14th - 15th February). Table S11. Metal results ( $\mathrm{mg} / \mathrm{kg}$ wet weight) of collected peppers in the markets (2014, 14th - 15th February). Table S12. Metal results (mg/ $\mathrm{kg}$ wet weight) of collected turnip greens in the markets $(2014,14$ th 15th February). Table S13. Maximum concentration of Lead and Cadmium in vegetables and fruits (Reg. (EC) n. 1881/2006). Appendix S1. Fifty-six samples of vegetables from six farms near Resit landfill were collected. (DOC $1168 \mathrm{~kb}$ )

\section{Abbreviations}

ADI: Acceptable Daily Intake; EDI: Estimated Daily Intake; EFSA: European Food Safety Authority; FAO: Food and Agriculture Organization; ICPAES: Inductively Coupled Plasma - Atomic Emission Spectrometry; ICPMS: Inductively Coupled Plasma - Mass Spectrometry; INRAN: National Research Institute of Food and Nutrition; NOAEL: Non Observed Adverse Effect Level; PTWI: Provisional Tolerable Weekly Intake; RF: Radio Frequency; SIN: Sites of National Interest; WHO: World Health Organization

\section{Funding}

Fondo sanitario nazionale (FSN).

\section{Availability of data and materials}

All data generated or analysed during this study are included in this published article and its Additional file 1.

\section{Authors' contributions}

VM, FC, MB fulfilled preparation and instrumental analysis of food products; they also contributed in statistic analysis of results. AG planned the sampling and performed the statistic analysis of results. GM planned this research upon request of the Procura della Repubblica di Napoli Nord. All authors contributed in writing the manuscript and approved it.

\section{Competing interests}

The authors declare that they have no competing interests.

\section{Publisher's Note}

Springer Nature remains neutral with regard to jurisdictional claims in published maps and institutional affiliations.

Received: 20 June 2018 Accepted: 30 August 2018

Published online: 11 September 2018

\section{References}

14G00013. Legge 6 febbraio 2016 n.6 - Conversione in legge con modificazion del decreto-legge 10 dicembre 2013. n. 136. recante disposizioni urgenti dirette a fronteggiare emergenze ambientali e industriali ed a favorire lo sviluppo delle aree interessate. 2016. http://www.gazzettaufficiale.it/eli/id/ 2014/02/08/14G00013/sg. Accessed 31 May 2018.

Adamo P, lavazzo P, Albanese S, Agrelli D, De Vivo B, Lima A. Bioavailability and soil-to-plant transfer factors as indicators of potentially toxic element contamination in agricultural soils. Sci Total Environ. 2014;500-501C:11-22.

Agricoltura oggi. Commercio Estero: è record Export Alimentare + 34,3 Mld. 2015 http://www.agricolturaoggi.com/site/index.php?option=com_content\&id= 5290\%3Acommercio-estero-e-record-export-alimentare\%2D\%2D343mld\&ltemid=61\&jjj=1483010220914. Accessed 31 May 2018.

Augustsson ALM, Uddh-Söderberg TE, Hogmalm KJ, Flipsson MEM. Metal uptake by home grown vegetables - the relative importance in human health risk assessments at contaminated sites. Environ Res. 2015;138:181-90.

Bashaa AM, Yasovardhana N, Satyanarayanaa SV, Subba Reddyb GV, Kumarc AV. Trace metals in vegetables and fruits cultivated around the surroundings of Tummalapalle uranium mining site, Andhra Pradesh, India. Toxicol Rep. 2014;1:505-12.

Beccaloni E, Vanni F, Beccaloni M, Carere M. Concentrations of arsenic, cadmium, lead and zinc in homegrown vegetables and fruits: estimated intake by population in an industrialized area of Sardinia, Italy. Microchem J. 2013;107:190-5.

Coldiretti. Commercio estero: record storico frutta e verdura italiana all'estero. 2016. https://www.coldiretti.it/economia/commercio-estero-record-storicofrutta-e-verdura-italiana-allestero. Accessed 31 May 2018.

COM/2000/0001. The precautionary principle. 2000. http://eur-lex.europa.eu/legalcontent/EN/TXT/?uri=URISERV\%3AI32042. Accessed 31 May 2018.

Di Lorenzo G, Federico P, De Placido S, Buonerba C. Increased risk of bladder cancer in critical areas at high pressure of pollution of the Campania region in Italy: a systematic review. Crit Rev Oncol Hematol. 2015;96:534-41.

DM 471/1991. Decreto Ministeriale del Ministero dell'Ambiente del 25 ottobre 1999. n.471. Regolamento recante criteri, procedure e modalità per la messa in sicurezza. la bonifica e il ripristino ambientale dei siti inquinati. ai sensi dell'articolo 17 del decreto legislativo 5 febbraio 1997. n. 22. e successive modificazioni e integrazioni. Gazzetta Ufficiale n. 293 del 15-12-1999 (Supplemento ordinario n.218). 1999.

EFSA Scientific report. Management of left-censored data in dietary exposure assessment of chemical substances. EFSA J. 2010;8(3):1557. https://doi.org/10. 2903/j.efsa.2010.1557

Ministero delle Politiche Agricole e Forestali/INRAN. Linee guida per una sana alimentazione italiana. 2003. http://www.salute.gov.it/portale/ documentazione/p6_2_2_1.jsp?id=652. Accessed 02 Sept 2018.

$\mathrm{FAO} / \mathrm{WHO}$. WHO and FAO announce global initiative to promote consumption of fruit and vegetables. 2003. http://www.who.int/mediacentre/releases/ 2003/pr84/en/. Accessed 31 May 2018.

II sole 24 ore. Campania, tengono le filiere. 2014. http://www.llsole24ore.com/art/ impresa-e-territori/2014-08-12/campania-tengono-filiere-063736.shtml?uuid= AB28nXjB\&fromSearch. Accessed 02 Sept 2018. 
Inaba T, Kobayashi E, Suwazono Y, Uetani M, Oishi M, Nakagawa H, Nogawa K. Estimation of cumulative cadmium intake causing Itai-itai disease. Toxicol Lett. 2005;159(2):192-201.

INRAN-SCAI 2005-06. INRAN - Istituto Nazionale di Ricerca per gli Alimenti e la Nutrizione - L'indagine nazionale sui consumi alimentari in Italia. 2010. http://nut.entecra.it/710/I_consumi_alimentari_INRAN-SCAI_2005-06.html. Accessed 31 May 2018

International Union of Pure and Applied Chemistry. "Heavy metals" - A meaningless term. IUPAC Technical Report - Pure Appl. Chem. N. 2002;74(5):793-807.

Kampa M, Castanas E. Human health effects of air pollution. Environ Pollut. 2008;151:362-7.

Lebel J, Mergler D, Branches F, Lucotte M, Amorim M, Larribe F, Dolbec J. Neurotoxic effects of low-level methylmercury contamination in the Amazonian basin. Environ Res. 1998;79A:20-32.

Leclercq C, Arcella D, Piccinelli R, Sette S, Le Donne C, Turrini A, On behalf of the INRAN-SCAI 2005-06 Study Group. The Italian National Food Consumption Survey INRAN-SCAI 2005-06: main results in terms of food consumption. Public Health Nutr. 2009;12(12):2504-32.

Luo C, Liu C, Wang Y, Liu X, Zhang F, Li G, Li X. Heavy metal contamination in soils and vegetables near an e-waste processing site, South China. J Hazard Mater. 2011;186:481-90.

NTR 24. Prodotti campani nel mondo: I'export continua a crescere. 2016. http:// www.ntr24.tv/2016/06/13/prodotti-campani-nel-mondo-lexport-continua-acrescere/. Accessed 31 May 2018.

Ogunkunle CO, Fatoba PO. Contamination and spatial distribution of heavy metals in topsoil surrounding a mega cement factory. Atmospheric Pollution Research. 2014;5:270-82.

OJ L 364 (20.12.2006) and updates. Commission Regulation (EC) N. 1881/2006 of 19th December 2006 Setting maximum levels for certain contaminants in foodstuffs. 2006; p. 5

OJ L 88 (29.03.2007) and updates. Commission Regulation (EC) N. 333/2007 of 28th March 2007 laying down the methods of sampling and analysis for the official control of the levels of lead. cadmium. mercury. inorganic tin. 3-MCPD and benzo(a)pyrene in foodstuffs. 2007; p. 29

Pellati R. FOSAN Frutta e verdura in Europa. 2012. http://www.fosan.it/notiziario/ 315_frutta_e_verdura_europa.html. Accessed 02 Sept 2018.

Piramide Alimentare Italiana- Guida settimanale per uno stile di vita salutare Sezione di Scienza dell'alimentazione Dipartimento di Fisiopatologia medica Sapienza Università di Roma; Gruppo di esperti (DM del 1.09.2003). 2003. http://www.piramideitaliana.it. Accessed 31 May 2018.

Quazi S, Sarkarb D, Datta R. Human health risk from arsenical pesticide contaminated soils: a long-term greenhouse study. J Hazard Mater. 2013;262:1031-8.

Rossi G, Pantanella F. I metalli pesanti nel sistema suolo-pianta. Ecoscienza. 2016:1:70-1.

RSPP 2009-2010. Relazione sullo stato sanitario del paese 2009-2010. 2010. http:// www.salute.gov.it/rssp/paginaParagrafoRssp.jsp?sezione= determinanti\&capitolo=ambiente\&id=2714. Accessed 31 May 2018.

SENTIERI - Studio Epidemiologico Nazionale dei Territori e degli Insediamenti Esposti a Rischio da Inquinamento: mortalità. incidenza oncologica e ricoveri ospedalieri. 2010. http://www.salute.gov.it/portale/documentazione/p6_2_2_ 1.jsp?lingua=italiano\&id=2147. Accessed 31 May 2018.

Szefer P, Nriagu JO. Mineral compo nents in food. Boca Raton, Florida: CRC Press; 2007.

Tang X, Pang Y, Ji P, Gao P, Nguyen TH, Subb Y. Cadmium uptake in aboveground parts of lettuce (Lactuca sativa L.). Ecotoxicol Environ Saf. 2016;125:102-6

Van Der Voet E, Salminen R, Eckelman M, Mudd G, Norgate T, Hischier R UNEP. Environmental Risks and Challenges of Anthropogenic Metals Flows and Cycles. A Report of the Working Group on the Global Metal Flows to the International Resource Panel. 2013. http://www.resourcepanel.org/reports/ environmental-risks-and-challenges-anthropogenic-metals-flows-and-cycles. Accessed 02 Sept 2018

Van Paemel M, Dierick N, Janssens G, Fievez V, De Smet S. Technical report submitted to EFSA - Selected trace and ultratrace elements: biological role, content in feed and requirements in animal nutrition - Element for risk assessment. 2010. http://www.efsa.europa.eu/it/supporting/pub/68e.html.

Vázquez M, Calatayud M, Jadán Piedra C, Chiocchetti GM, Vélez D, Devesa V. Toxic trace elements at gastrointestinal level. Food Chem Toxicol. 2015;86:163-75.
WHO/SDE/WSH/03.04/74. World Health Organization. 2003. Antimony in drinking water - Background document for development of WHO Guidelines for drinking water quality. 2003. http://www.who.int/water_sanitation_health/ dwq/chemicals/antimony.pdf. Accessed 31 May 2018.

Wolz S, Fenske RA, Simcox NJ, Palcisko G, Kissel JC. Residential arsenic and lead levels in an agricultural community with a history of lead arsenate use. Enviromental Research. 2003;93:293-300.

\section{Ready to submit your research? Choose BMC and benefit from:}

- fast, convenient online submission

- thorough peer review by experienced researchers in your field

- rapid publication on acceptance

- support for research data, including large and complex data types

- gold Open Access which fosters wider collaboration and increased citations

- maximum visibility for your research: over $100 \mathrm{M}$ website views per year

At BMC, research is always in progress.

Learn more biomedcentral.com/submissions 